\title{
PROBLEMS OF CONTROL IN THE SOCIAL SPHERE
}

\author{
Venelin Terziev ${ }^{1}$ and Evgeniy Stoyanov ${ }^{2}$ \\ ${ }^{1}$ Professor, Ph.D., D.Sc. (National Security), D.Sc. (Ec.), University of Rousse, Rousse, Bulgaria, \\ National Military University, Veliko Tarnovo, Bulgaria, University of Telecommunications and Post, \\ Sofia, Bulgaria \\ ${ }^{2}$ Professor, Ph.D., D.Sc., National Military University, Veliko Tarnovo, Bulgaria
}

\begin{abstract}
The content is more broadly focused on that part of public relations where there is an increasing control deficit. The issue that draws attention and concentrates on itself the analysis is the operation of the administrative control system and its impact on the actions and performance of the executive authority. The discovery of a small part of the problems registered in this sphere is an opportunity to look for options for their control and alternatives for their final solution.
\end{abstract}

Keywords: Control, analysis, competence, legal personality, power.

\section{MAIN TEXT}

The conception of the material is related to the disclosure of some essential features of the administrative control considered as an essential part of social control in order to seek solutions to problems arising from its operation. In this context, the system of administrative control, in its entirety including grounds, conditions, subjects, objects, standards and tools, can be recognized as an object. The content of the main thesis reveals that the control in the social sphere, and in particular its administrative form, has a specific character, predetermined by the fact that it is predominantly implemented by the executive power on the basis of control competence, built independently by virtue of the law and for that reason the emerging control deviations are relatively difficult to overcome. The essential characteristic and significance of the specific purpose and subject matter create the conditions in the accumulation of evidence on the stated thesis to resort to different forms of analysis. The nature and peculiarities of the subject suggest that evidence can be found in economic, legal and philosophical literature.

Undeniable is the fact that accumulated managerial experience, theoretical developments, scientific trends, and management schools are the factors that form the management knowledge known as Management Theory. Still, in the practical manifestations of this knowledge system there is a growing institutionalism. In the social strata its material expression appears in the face of institution management. The analysis of the 
historical facts and the development of the society itself prove that in any complex modern production, where different skilled and experienced specialists with diverse professions are present, it is impossible to achieve good results without applying management. Unlike today, its presence under the old elementary production systems with typological recurrent actions and lacking or uniform qualification of the staff was not necessary.

On this occasion, P. Dracker argues that its appearance "turned the knowledge from public adornment and luxury into the true capital of every economy" (1992). K. Kamenov adds that "the explosion in education, i.e. the accumulation of knowledge" precedes the emergence of modern management, in other words, knowledge is a reason, and management is a result (2012). Specifically related to the chronology of facts, the knowledge accumulated until the early 50's began to find its institutional implementation afterwards. Analyses of current results have shown that this huge gap has been narrowing over the years, based on the faster approbated discoveries and developments.

The strengthening of the place and the role of the "management" institution in the improvement of the contemporary society and in the processes that take place in the functioning of the global economic system create prerequisites for the formulation of some of its goals:

1) Deliberate unification of human efforts and intentions;

2) Effective coordination in collective actions;

3) Achieving motivational effect thanks to adequate structuring.

4) Controlled transformation of ideas into specific goods.

The critical reading of many papers on management theory and administration provides evidence that the majority of authors engage the content of management primarily with the presence and implementation of a system of core functions that justify the work of an organization. What is interesting is the fact that almost all of them are turning to the details of the problem and finding a specific answer, i.e. number of functions, boundaries, mode of interaction, etc.

Perhaps they are missing the more significant, or the authors just neglect that the manifestations of management reproduce a social effect. The acquisition of institutionalism (2013), according to economic theories, proves that the idea of implementation of the management institution, sociologizing the management knowledge, acquires an infinite market, organized by the participation of all economic subjects in the structuring of the global economic system. From the standpoint of society, it is actually an effect or a reaction to perceiving the institutional presence. But from the perspective of analysing the essence of the social phenomenon "management", it may be appropriate to consider its perception as a key feature without which management cannot function properly and exist. In this context Kamenov defines quality as a social function. The imposition of the social function to management has its conceptual basis, revealed by Drucker. Its contents include:

1) development of human resources focused on team and efficiency;

2) improving the unifying role of human culture;

3) the purposeful creation of an organizational value system;

4) promoting the organization as a constructive environment;

5) optimizing communications;

6) awareness of personal responsibility;

7) deepening the connection between market recognition - efficiency.

The explanations given in the scientific papers prove that it is difficult to make a complete and comprehensive characteristic of management. On the basis of this, it can be summed up that management is a theoretically grounded and practically oriented, systematized management knowledge that organizes the process of work carried out with the active participation of personalities and personal formations engaged in the effective and efficient achievement of organizational goals in the conditions of a changing competitive environment.

Based on definitions of management given by Donnelly, Ivanchevich, Daft, King, Cleland and their followers and adherents, it has been found to be common in defining the presence of all actions carried out on this occasion in the structure of the single aggregation process. Another important finding is related to the presentation of the practical implementation of the management knowledge, i.e. of management as a system that justifies the view that this process is of a systemic nature. It is precisely where, as claimed by R. Daft, 
the management functions manifest themselves that give the system an integrity and unity and guarantee the implementation of the goals set for it. And if here, it is added the fact that the systems are functioning continuously or at least relatively long, then the whole process is constantly showing its cyclical character.

According to $\mathrm{V}$. Muhin, the management process is defined as a one-time or multiple continuous process of managing and transferring the tasks of the goals of the subordinate objects (2006). Thus, it is believed that a process that takes place in a system (organization or state) and materializes the knowledge of management in practice, while cyclically based on the management functions and at the same time using the necessary resources effectively fulfils the objectives set, is the "classical" management process.

While it is proven that all elements of its development have a place and a role due to the set objective of the expose, the focus is on the final stage of the management process associated with the control function manifestations.

The definition of the term "control" and its study can be made from different points of view. Control theory has many definitions of its essence, which in the prevailing cases only touches the external forms of manifestation and a specific way of existence. Most authors regard it as a function of government, more precisely as an organization in the system of the state and a set of functions, continuation of the state functions as a monitoring of the changes in the parameters of the system mechanism, etc.

The series of opinions may seem even more impressive and detailed, but the overall conclusion will not be changed: the state function, the management function, the management system, etc. are all externalities and signs of a particular form of control. The internal aspects, the logic of the ongoing processes, the persistent characteristics of the public attitude, are lacking, because the control is manifested before the state institution and its forms of governance, before the structures, systems and functions formed in them.

Generally, every structure necessarily contains the control function that determines the behavior of the system and its ability to develop in strictly defined parameters until the goal is achieved. In this context, the definition of $\mathrm{E}$. Mateev is also expressed that the essence of management, perceived as setting a specific system of meanings, determining the norm $X_{1}, X_{2} \ldots X_{N}$ for the parameters of the functioning of the managed system, as of a system of meanings, $Y_{1}, Y_{2} \ldots Y_{N}$ for the parameters of the operation of its subsystems whose achievement leads to the implementation of the meanings $X_{1}, X_{2} \ldots X$. (1987)

In management theory, it is known that the norm is a solution to the parameters in which the system is developed, its purpose and the objectives for each subsystem, each element and process. The control function is manifested not only to determine the performance of the norm but also to assess the quality of the decision [6]. Here, it is worth noting that the norm is not a canon or dogma with a specific limiting character, but a precise expression of the most satisfying values of the decision taken, presenting its significance and potential. The management decision regarding the totality and meanings of the system of parameter meanings implies the presence of several components. Each norm, reflecting a specific management solution, is related to the reconciliation of a certain range of values of controllable and uncontrollable parameters. The classification of the parameters is implemented on the basis of the objective possibility of the norm to influence them, and it is especially important to note that the uncontrollable parameters for the specific norm also influence its formulation. When combining the controllable and uncontrollable parameters, a significant factor is defined for the specific norm, internal and external thresholds, called limitations on possible values of the parameters that characterize both their content and the relations between them.

In the process of forming the management solution, the possible outcomes are analysed by linking them to the values of the resultant parameters and several possible outcomes are formed, providing conditions for fixing selection criteria. The particular choice is related to the possibility of achieving desired values of the resultant parameters. It is necessary to have at least two variants of combinations of the values of the controllable parameters leading to acceptable results for the deciding subject (1986).

The process of setting a rule in making management decisions can be considered in two aspects with regards to control: First. Control is manifested in relation to the reality of the chosen norm, its proper structural order for time and space, its adaptability to the system's capabilities, the correspondence with the best achievements in other systems. The assessment of the system's norm from the standpoint of established criteria and requirements of the leading achievements in the world becomes an objective need for development, a mandatory condition for influence in control. Second. Control assesses the presence of quantitative and qualitative dimensions in the norm, the precise characteristics of the controlled parameters. A norm in which time and space are absent, as well as quantitative and qualitative dimensions, responsibilities and incentives, cannot be controlled. It deprives the management process of the development of rights and feedback, of its essence and content. 
The purpose of control as a function of management is to ensure the implementation and updating of the assigned target function of the managed system on the basis of the feedback principle. According to this principle, the management can only be implemented when the controllers receive information on the progress of the assigned state. Although the brief analysis of the management, its system and one of the main functions of control are considered in principle in the above rows, with regards to their interpretation and presence in the work of the state, considered as the ultimate institution, both their form and content acquire other meaning.

The starting point is the routine attachment of the essential characteristic of control to the legal nature of government. In it, as a rule, the potentials of leadership, organization and control are consolidated, as this is how the state's executive and governmental activities are formed.

The supremacy of the state institution itself gives this functional trinity a predominantly authoritarian character. It is in this context that the government, implemented by the state, acquires another nature, which said in a different way perceives a new executive character. The interpretation of this peculiarity is based on a typical mechanism, which is characteristic of the state, namely that a management-control effect is implemented with state-managerial tools (1976) and, at the same time, the system of government is a strictly managed system. This proves that the key factor in the work of the state in general and, more specifically, in this system is the presence of power resources predominantly provided to the government.

From a legal point of view and in the context of the above-mentioned lines, government is a legal, power and regulatory activity aimed at general management, organization and control, conducted in all public spheres. Structurally, according to the principle of administrative and hierarchical subordination, all entities, individuals and legal entities, are placed under the subordination of the executive authority with full respect of the will of the sovereign.

Given that in principle the grounds for control are justified by the critical public attitude and its functional presence in the structure of the governance process considered as part of the state government, both the analysis and content acquire new meaning. It is precisely in this context that administrative control appears and is established even in ancient Rome (2010). If a brief characteristic is to be made of this specific type of control the starting point is that its subject is individuals and bodies of executive authority. The relations within the system of the administrative power are organized according to the principle of the superior.

The established hierarchical structure shows that the governing status of an authority is justified by its administrative legal personality or by its positioning in the particular hierarchy. The question of administrative personality is explained by the theoretical understanding of competence. It distinguishes quantitative trend and legal personality principles. While competence is seen as a complex object of analysis, the subject of the study draws attention to control competence. It is considered to guarantee the management status and ensure obedience. Actually, it is the factor ensuring the establishment of dependency on authority. In this sense, the mentioned dependence, existing in the essential characteristic of the bodies of the executive authority, creates conditions for the implication of certain functions. Thus, control makes it possible to establish self-empowerment by law.

On the basis of the theoretical developments and in the sphere of governance and in the sphere of law, the state considered as a framework in which the administrative control functions and develops, adopts the following type and content: entity - the executive authority, object - processes and actions of general government of society, standards - the legal basis, and the instrumentation - the control competence. From this point of view, the interesting moment is the toolbox. The legislator has foreseen the possibility of controlling competence being considered as a competence by level and/or as competence based on the power of the law.

Although the above proves that administrative control has a good level of development and rational, regulative justification, the results in society dispute this statement in substantial degree.

The first and undisputable problem is the lack of unanimity and synergy on the part of the executive authority.

The second problem stems from the existing but low-performing control, even at the highest level - in the National Assembly.

The third problem is directly related to, or perhaps is the result of, a different interpretation of the notion of "competence" at personal and institutional level.

The fourth problem reveals the principle - not to seek consolidation of effort, but to maintain confrontation or self-proclaim. 
The fifth problem may be interdisciplinary in nature and is related to the influence of authority on the preservation of morality and the value system in the individuals occupying governmental posts.

The content of the study creates the possibility to structure the conclusion that administrative control is a sufficiently important and essential factor for the sustainability of society. The rational and legitimate resolution of these problems can only accelerate the processes of creating a successful state with effectively functioning institutions, organized, managed and supervised by an authoritative executive power. In this way, the public will have the necessary degree of confidence that the new politicians' policies will reveal the art of their capabilities.

The content of the study creates the possibility to structure the conclusion that administrative control is a sufficiently important and essential factor for the sustainability of society. The rational and legitimate resolution of these problems can only accelerate the processes of establishing a successful state with effectively functioning institutions, organized, managed and controlled by an authoritative executive power. In this way, the public will have the necessary degree of confidence that the new policies of the politicians will reveal the art of their capabilities (2017a, 2017b, 2017c, 2017d,2017e, 2017f, 2016).

\section{REFERENCES LIST}

Kozlov, Y.,(1976),Administrativnie pravootnosheniya, Pravo, Moskva.

Akoff, R.,(1986), Isskustvoresheniya problem, Radio itelevidenie, Moskva.

Mateev, E.,(1987), Struktura I upravlenienaikonomicheskatasistema, Naukaiizkustvo, Sofiya.

Drakar , P.,(1992), Noviterealnosti, Sofiya, Hristo Botev.

Dinev, M.,(1999), Kontrol v sotsialnotoupravlenie, Trakiya-M, Sofiya.

Muhin, V.,(2006) Issledovanie system upravleniya, Ekzamen, Moskva.

Stoyanov, E.,(2010), Finansovkontrol, Libra skorp, Burgas.

Kamenov, K.,(2012), Osnovinaupravlenieto, VelikoTarnovo, Faber.

Stoyanov, E.,(2013), Odit - iztochnitsiiinstitutsionalizatsiya, Burgas, Flat.

Терзиев. В., Стоянов. Е., Эволюция понимания аудита ( Evolution in the concepts about audit), Международный научный журнал „Интернаука.

Терзиев. В., Стоянов. Е., Функциональная характеристика и развитие идеи контроля (Functional characteristics and development of the idea for control), Международный научный журнал „Интернаука“.

Терзиев. В., Стоянов. Е, Формальные аудиторские проявления и институциональность (Formal audit acts and institutionality), Международный научный журнал „Интернаука“ ,

Терзиев. В, Стоянов. Е.,(2016) Формальные аудиторские проявления и институциональность. Международный научный журнал „Символ науки“ №3/2016.

Terziev. V. , Stoyanov. E., Georgiev.M.,(2017a), The factotor information in the making of "The right” decision (Факторът информация в процеса на вземане на „Вярно“ решение), Scientific journal „Economics and finance”, Publishing house „BREEZE“, Montreal, Canada.

Terziev. V. , Stoyanov. E., Georgiev.M.,(2017b), One solution for costs minimanization in the banking sector (Едно решение за минимизиране на разходите в банковия сектор) , Scientific journal „Economics and finance”, Publishing house „BREEZE“, Montreal, Canada.

Terziev. V. , Stoyanov. E., Georgiev.M.,(2017c), Accountable regulation of foreign exchange operations (Отчетно регулиране на валутните операции), Scientific journal „Economics and finance”, Publishing house „BREEZE“, Montreal, Canada.

Terziev. V. , Stoyanov. E., Georgiev.M.,(2017d), Specifics of control in operations with precious metals and precious stones (Особености на контрола при операции с благородни метали и скъпоценни 
камъни), Scientific journal „Economics and finance”, Publishing house „BREEZE“, Montreal, Canada.

Terziev. V. , Stoyanov. E., Georgiev.M.,(2017e), Institutional team work-opportunity for improvement of financial control (Екипната институционална работа-възможност за усъвършенстване на финансовия контрол) Scientific journal „Economics and finance”, Publishing house „BREEZE“, Montreal, Canada.

Терзиев. В, Стоянов. Е., Георгиев.М,(2017f), Сбалансированная карта, как альтернатива для малого бизнеса, Международный научный журнал „Инновационная наука“ №2/2017. 